DOI: 10.5817/CZ.MUNI.P210-6840-2014-51

\title{
SIGNIFICANCE OF EU FUNDS IN THE CREATION OF SPORT AND RECREATION INFRASTRUCTURE IN POLAND IN THE CONTEXT OF THE COHESION POLICY
}

\author{
JADWIGA BIEGAőSKA
}

\section{STEFANIA ŚRODA-MURAWSKA}

\section{ELE BIETA GRZELAK-KOSTULSKA}

\author{
Department of Urban Studies and Regional Development \\ Faculty of Earth Sciences \\ Nicolaus Copernicus University \\ $\triangle$ ul. Lwowska 1, 87-100 Torun, Poland \\ E-mail: jadwigab@umk.pl,steffi@umk.pl,grzelak@umk.pl
}

\begin{abstract}
Annotation
The paper aims at analyzing the significance of EU funds in the creation of sport and recreation infrastructure in Poland in the context of the Cohesion Policy. The research has been conducted on the basis of data derived from the official websites of the Regional Operational Program for Kujawsko-Pomorskie Voivodship 2007-2013 (ROP WKP). The information on applications approved by the European Commission in the 2007-2013 programming period available at the websites have been currently upgraded and monitored. In order to achieve the aim of a research analysis have included all investments in sport and recreation infrastructure financed from EU funds. From database, which contained 6,117 applications implemented under the Cohesion Policy, 227 applications related to sport and recreation infrastructure have been analyzed. It has been proved in the paper that EU funds have contributed significantly to the creation of sport and recreation infrastructure improving, among others, quality of life.
\end{abstract}

\section{Key words}

Poland, Cohesion Policy, EU funds, sport and recreation infrastructure, quality of life.

JEL classification: $O 21, R 1, R 5$.

\section{Introduction}

Cohesion Policy pursued by the European Union (EU) supports all actions, which tend to align economic and social conditions in all regions of the EU. The implementation of the Cohesion Policy has been carried out through operational programs, i.e. financial support granted NUTS 3 regions where per capita income does not exceed $75 \%$ of the EU average. The main objectives supported within the Cohesion Policy are as follows: convergence (i.e. cohesion), improving the competitiveness of regions, and European territorial cooperation. Among objectives mentioned above until $82 \%$ of total financial support has been allocated to the convergence in the field of infrastructure development, economic and population potential of the poorest regions.

Such proportions in financial support reflect the actual needs of regions benefiting from the EU aid. We should remember that in the countries of Central and Eastern Europe (ECE), which have been presently the main beneficiaries of the EU aid, since the end of the World War II until the beginning of transition, most investments had been related to the development of industry (SzymaCka, 2004). As a consequence it has been observed the underdevelopment of infrastructure, especially social one, in ECE countries compared to the countries of Western Europe. 
Infrastructure is the essential element of the space of every country. It creates appropriate conditions for living and enables proper functioning of all sectors of economy. Additionally, level of infrastructure development measured by various indicators is considered one of the most important determinants of socio-economic development (Lijewski, 2004). The low or high degree of the saturation of technical or social infrastructure may in fact hinder or stimulate most economic initiatives and significantly affect the attractiveness of settlements (Frenkel, 1999; SzymaGka, Biega $(\mathrm{k} k$ a, 2011, 2012). Capital expenditure on infrastructure becomes the starting point for the transformation of regions, the modification of the directions of population flows (as pulling and pushing factor), growth in economic investments, more effective usage of tourist and recreational advantages, but mainly for the improvement of quality of life (QOL) (cf. Heffner 2001, Ba Gki 2008), which besides the competitiveness of regions is one of the most important priorities of the EU Cohesion Policy.

The concept of QOL which has been intensively developed within social sciences since 1970s (Campbell, 1976; Campbell et al., 1976; Diener, Suh, 1997; Susniene, Jurkauskas, 2009; Wnuk, Marcinkowski, 2012) has lately become the subject of the increasing interest of state and local governments. In turn, improving quality of life and reducing disparities in the material and social circumstances of the different groups of population is the primary objective of the contemporary concepts of socio-economic development (GUS, 2013; środa-Murawska, 2013).

Quality of life is one of important concepts widely discussed among the scientists (e.g., Susniene, Jurkauskas, 2009; Trzebiatowski, 2011; Walczak, Tomczak, 2011; Wnuk, Marcinkowski, 2012), practitioners and decision-makers of social life. However, the notion is significant, there has not been still developed its universal definition. According to the most commonly used definition, proposed by World Health Organization (WHOQOL Group, 1997: 1), áquality of lifeôis

ñindividualôs perception of their position in life in the context of the culture and value systems in which they live and in relation to their goals, expectations, standards and concerns. It is a broad ranging concept affected in a complex way by the personô physical health, psychological state, level of independence, social relationships, personal beliefs and their relationship to salient features of their environment.ò

Considering quality of life most researchers distinguish its objective and subjective indicators/criteria (Campbell, 1981; Trzebiatowski, 2011). Objective quality of life includes the conditions of the existence of particular social groups, i.e. material life conditions, health, education, economic activity, leisure time and social relations, personal safety, the quality of state and its ability to provide people with basic rights and the manners of the implementation of rights, as well as the quality of natural environment and the quality of infrastructure in the place of residence. In turn, subjective criteria relate to the perception of quality of life. Therefore they are connected with satisfaction that people gain from the various aspects of life as a whole, as well as from psychical well-being and experienced emotional states (GUS, 2013).

Taking into account the objective and subjective criteria we can assume that infrastructure, including sport and recreation one, may positively affect quality of life. Accessibility of sport and recreation facilities, their equipment, the animation of sport and cultural events influence on the one hand the quality of infrastructure, on the other hand, on way of spending leisure time and social inclusion. Thus, the EU Cohesion Policy including investments among others in the field of sport and recreation infrastructure has contributed to improving quality of life.

In the contemporary world sport is actually one of the most significant civilization, cultural and social values (Ministerstwo Sportu, 2007). It is estimated that at the turn of $21^{\text {st }}$ century sport in various forms was practiced or was connected with the activity of more than billion people in the World (Godlewski, 2004, 2011). Sport as the field of life whose potential has been increasing has appeared more and more often in the development documents of countries, regions and cities (Motek, Bogacka, 2012). The essential role of sport has been also noticed in the EU institutions. In ñWhite Paper on Sportò (Biağ ksiŃga na temat sportu, 2007), which is the result of the work of the European Council 
widely consulted with Olympic committees, sport federations and the Member States since 2005, attention is mainly focused on two aspects of sport: economic $i \vec{i}$ connected with the role of sport in the creation of economic growth and new jobs, and social $\ddot{i}$ in which sport is treated as social phenomenon stimulating such values as peace, tolerance, mutual understanding, and education. In this sense, sport enables the achievement of strategic objectives within shaping active citizenship and wellbeing in the EU states.

As noticed in the Strategy for the Development of Sport in Poland until Year 2015 (Strategia Rozwoju Sportu w Polsce do Roku 2015, 2007), sport has not been the priority area of state policy in the recent decades. It has resulted in the decrease in physical activity among society. According to the WHO research (WHO, 2002, cf. Ministerstwo Sportu, 2007), only 7\% of Poles take regular physical activity and $48 \%$ - do not practice any physical activity or do it incidentally. Thus, despite the relatively high popularity of sport and sport events, the advantages of physical activity are still underestimated or unknown among Poles. Additionally, considering the increasing life expectancy of population (cf. Grzelak-Kostulska, Hoğwiecka, 2009, 2010; Biega Gka, 2013) the observed trend is particular threat to health and quality of life (Ministerstwo Sportu, 2007).

One of the main reasons of not enough physical activity among Poles has been noticed in the not satisfying condition of sport infrastructure. In the years 1995-2007, i.e., before the National Cohesion Strategy 2007-2013 started, 3,200 sport facilities had been completed. Anyhow, in accordance with the opinion of the Ministry of Sport in Poland, even then facilities for qualified sport and recreation activity did not fulfill European standards, neither in quantitative nor qualitative terms. Large part of facilities was neglected and hardly accessible for persons with disabilities (Ministerstwo Sportu, 2007). Therefore, building modern sport infrastructure has been accepted as one of the priority required actions.

\section{Materials and methods}

The study covers the years 2007-2013, i.e., when the National Cohesion Policy was implemented.

The research has been conducted in the Kujawsko-Pomorskie voivodship (WKP) (administrative region of the $1^{\text {st }}$ order in Poland), which is located in the central part of Poland. The analyzed voivodship is inhabited by $2.1 \mathrm{mln}$ persons $\left(10^{\text {th }}\right.$ place among 16 voivodships in Poland), which represents 5.4\% of total Polish population number. The area of analyzed voivodship comprises 18.0 thousand sq. km, which constitutes as much as $5.7 \%$ of the total area of Poland $\left(10^{\text {th }}\right.$ place among 16 voivodships in Poland). According to the administrative division of Poland, the WKP includes 92 rural, 35 urban-rural and 17 urban gminas (administrative regions of the $3^{\text {rd }}$ order) (state as of 2013).

The research has been curried out on the basis of data derived from the official websites of the Regional Operational Program for Kujawsko-Pomorskie Voivodship 2007-2013 (ROP WKP) (http://www.mojregion.eu/regionalny-program-operacyjny-wojewodztwa-kujawsko-pomorskiego/oprogramie.html). The information on applications (projects) approved by the European Commission in the 2007-2013 programming period available at the websites have been currently upgraded and monitored. The information has included as follows: full name of beneficiary, the title of application, area where the application has been implemented, operational program, in which application has been approved, value of financial support, and the total value of projects.

In the context of the Cohesion Policy, it should be noted that Poland, as one of the countries which joined the EU relatively recently (2004), has tended to improve the condition and the accessibility of infrastructure benefited firstly from the Instruments of Pre-Accession Assistance (IPA). In the years 2004-2006, the projects related to sport infrastructure were implemented mainly through such instruments as Integrated Regional Operation Program, Sectoral Operational Program đ́Restructurization and Modernization of the Food Sector and Rural Developmentôand seven programs of transborder cooperation (Interreg) (Ministerstwo Rozwoju Regionalnego). Finally, in the years 2007-2013, Poland took part fully in the implementation of the Cohesion Policy. In this programming 
period sport and recreation infrastructure might have been supported from the following programs: Operational Program đ́nfrastructure and Environmentô and Rural Development Program for 20072013 (Ministerstwo Rozwoju Regionalnego; ǴŃzzak, 2010). Great opportunities related to investments in sport and recreation infrastructure were also offered by regional operational programs. What is worth emphasizing, every voivodship in Poland within their own operational programs provided some funds for this type of infrastructure (Ministerstwo Rozwoju Regionalnego).

The paper aims at analyzing the significance of EU funds in the creation of sport and recreation infrastructure in Poland in the context of the Cohesion Policy.

In order to achieve the aim of research analysis has included all projects in sport and recreation infrastructure financed from EU funds. From database which contained 6,117 applications implemented under the Cohesion Policy in the WKP 227 applications related to sport and recreation infrastructure have been considered. These applications have been analyzed in the context of the degree of realization in the projects investment in sport and recreational infrastructure; operational programs, in which the projects has been approved; beneficiaries, which achieved financial support for the realization of the projects; value of financial support; and the total value of the projects.

\section{Research results}

The main objectives, which have been realized in RPO WKP in 2007-2013, have been: (a) the improvement of voivodship competitiveness as the field of economic activity, investment location, attractiveness for living and spending leisure time for residents and tourists, (b) the increase in the competitiveness of the WKP economy, (c) the improvement of residentsôstandard and quality of life. The RPO WKP has been implemented through realization of eight main objectives defined as priority axes. Among eight priority axes important position has been ascribed sport infrastructure, which has been implemented and financed mainly within the development of social infrastructure and the support for tourism development (Grzelak-Kostulska, Hoğwiecka, 2013), and to the lesser extent in the other axes. It is worth mentioning that support for sport infrastructure implemented in the WKP in the years 2007-2013 has been also dictated by the observations made in the period of the implementation of pre-accession funds in the years 2004-2006. Then the largest demand in comparison with the allocation referred to (besides environment protection infrastructure, health protection infrastructure, educational infrastructure) sport infrastructure (RPO WKP 2007-2013).

Among 6,117 applications approved in the WKP in the analyzed period 290, i.e., 5\% of total their number has concerned sport. In turn, in the total number of applications related to sport, 227 applications, i.e. $78.3 \%$ of all applications concerning sport, has been connected with investment in sport and recreation infrastructure. Such proportions seem to confirm the notice about deficiency in the accessibility and appropriate standard of sport infrastructure in the analyzed voivodship.

Most applications, i.e., 189 (83.3\%), for investment in sport and recreation infrastructure in the analyzed voivodship, has been accepted within Rural Development Program. It should be noted that main beneficiaries in the program might have been rural areas and little towns, and financial support for sport and recreation infrastructure might have been achieved after application within Axis 3 related inter alia to quality of life (cf. Ministerstwo Rolnictwa i Rozwoju Wsi). It indicates that large demand for this type of infrastructure is observed mainly in small-sized settlements. Besides Rural Development Program, 38 applications have been accepted within the Regional Operational Program of Kujawsko-Pomorskie Voivodship.

Applications related to sport and recreation infrastructure have been also analyzed by the degree of realization in the project investment stricte in sport and recreational infrastructure. Among 227 applications, most of them, i.e., $132(58.1 \%)$ have been fully intended for the realization of investment in sport and recreation infrastructure, 94 applications (41.4\%) - only partly and one application $(0.4 \%)$ - only in some little degree. 
In the research the structure of beneficiaries, which have achieved financial support for investment in sport and recreation infrastructure in the WKP, has been also analyzed. As it has been shown in Table 1 , the vast majority of applications related to sport and recreation infrastructure has been realized by local government units, i.e. gmina, poviat (administrative region of the $2^{\text {nd }}$ order in Poland) and voivodship, which in the years 2007-2013 acquired financial support from EU for $88.1 \%$ of all analyzed projects. Against the background of local government units, the most active within acquisition of EU funds have been gminas, which gained financial support for $82.8 \%$ of all analyzed projects. Additionally, 5.3\% of all applications related to sport and recreation infrastructure have been realized by institutions for which sport is statutory activity, $4.8 \%$ by non-governmental organizations (NGOs) active in sport, and $1.8 \%$ by private firms for which the main field of activity is sport.

Considering applications in the context of the type of beneficiary it should be emphasized that dominant activity in this area observed among local government units, mainly gminas, has resulted from their duties described in the regulations on local government. For example according to the Act of 8 March 1990 on local government (published in Dz.U. 1990 No. 19) one of the duties of gmina includes the fulfillment of the needs of community inter alia in physical activity, recreational areas and sport facilities (cf. Basi@ka-Zych, Lubowiecki-Vikuk, 2010; Godlewski, 2011). As mentioned above, large responsibility for the accessibility and high standard of sport and recreation infrastructure ascribed local governments reflects also the vision of Ministry of Sport in Poland (cf. Ministerstwo Sportu, 2007). It should be also noticed that local government units in the WKP applying actively for EU funds among others for sport and recreation infrastructure, in the same projects often asked for financial support for investment in the improvement of educational infrastructure and in the same time the quality of educational services (their assumption has been that new or modernized sport and recreation infrastructure should be a part of educational infrastructure) and for the tourist infrastructure and in the same time the improvement of the quality of tourist services. The observation has been confirmed by the data set in Table 1, on the basis of which we can conclude that local government units in the analyzed voivodship against the background of the other beneficiaries has had the largest number of applications related to sport and infrastructure approved but in the same time they have implemented the lowest share of applications related fully to this type of infrastructure.

Tab. 1: Structure of applications related to sport and recreational infrastructure in the WKP in the years 2007-2013 by beneficiary and degree of realization in the project investment in sport and recreation infrastructure

\begin{tabular}{|l|c|c|c|c|c|c|c|c|}
\hline Beneficiary & $\mathrm{A}$ & $\mathrm{B} 1$ & $\mathrm{~B} 2$ & $\mathrm{~B} 3$ & $\mathrm{C} 1$ & $\mathrm{C} 2$ & $\mathrm{C} 3$ & all** \\
\hline Gminas & 188 & 106 & 82 & 0 & 56.4 & 43.6 & 0.0 & 82.8 \\
\hline Poviats & 6 & 2 & 4 & 0 & 33.3 & 66.7 & 0.0 & 2.6 \\
\hline Voivodship & 6 & 4 & 2 & 0 & 66.7 & 33.3 & 0.0 & 2.6 \\
\hline Institutions & 12 & 8 & 4 & 0 & 66.7 & 33.3 & 0.0 & 5.3 \\
\hline NGOs & 11 & 8 & 2 & 1 & 72.7 & 18.2 & 9.1 & 4.8 \\
\hline Firms & 4 & 4 & 0 & 0 & 100.0 & 0.0 & 0.0 & 1.8 \\
\hline Total & 227 & 132 & 94 & 1 & 58.1 & 41.4 & 0.4 & 100.0 \\
\hline
\end{tabular}

Explanation: A ï number of all applications (projects); B1 ï number of projects fully related to sport and recreation infrastructure; B2 - number of projects partly related to sport and recreation infrastructure; B3 number of projects only in some little degree related to sport and recreation infrastructure; $\mathrm{C} 1 \mathrm{i}$ percentage of projects fully related to sport and recreation infrastructure (every beneficiary as 100\%); $\mathrm{C} 2 \mathrm{i}$ percentage of projects partly related to sport and recreation infrastructure (every beneficiary as 100\%); C3 ï percentage of projects only in some little degree related to sport and recreation infrastructure (every beneficiary as 100\%); D percentage of projects related to sport and recreation infrastructure by beneficiary (all projects as 100\%)

Source: Own elaboration on the basis of data derived from RPO WKP for the years 2007-2013

In order to analyze the significance of EU funds for the creation of sport and recreation infrastructure we also considered the value of financial support for projects (in PLN) and the total value of projects related to this type of infrastructure (in PLN) (Table 2). 
Tab. 2: Structure of applications (projects) related to sport and recreation infrastructure in the WKP in the years 2007-2013 by beneficiary and $(A)$ value of financial support from $E U$ for projects (in PLN); (B) total value of projects (in PLN); (C) percentage of financial support from $E U$ in the total value of projects (in \%)

\begin{tabular}{|l|c|c|c|}
\hline Beneficiary & A & B & C \\
\hline Gminas & $158,928,129$ & $296,143,113$ & 53.7 \\
\hline Poviats & $20,302,661$ & $37,829,372$ & 53.7 \\
\hline Voivodship & $48,979,346$ & $181,484,967$ & 27.0 \\
\hline Institutions & $29,795,963$ & $43,494,318$ & 68.5 \\
\hline NGOs & $4,993,682$ & $98,64,141$ & 50.6 \\
\hline Firms & $1,606,709$ & $2,833,376$ & 56.7 \\
\hline Total & $264,606,490$ & $571,649,287$ & 46.3 \\
\hline
\end{tabular}

Source: Own elaboration on the basis of data derived from RPO WKP for the years 2007-2013

The value of the financial support of all analyzed projects approved and implemented in the WKP in the years $2007-2013$ has amounted to $264,606,490$ PLN, i.e., $46.3 \%$ of the total value of financial support in the projects related to sport and recreation infrastructure (and 3\% of the financial support of all projects implemented in the WKP). Among all beneficiaries the largest financial support $(158,928,129$ PLN) for sport and recreation infrastructure has been gained by gminas, the largest value has been also registered for the total value of their applications $(296,143,113$ PLN). In turn, the highest share of financial support in the total value of applications related to sport and recreation infrastructure have been achieved by institutions (68.5\%), then by firms $(56.7 \%)$, gminas $(53.7 \%)$, poviats $(53.7 \%)$, NGOs (50.6\%), and voivodship (27.\%).

\section{Conclusion}

In the following paper we have shown that EU funds have contributed significantly to the creation of sport and recreation infrastructure in Poland. Considering fact that sport has not been the priority area of state policy in the recent decades and responsibility for the provision and the high standard of sport infrastructure has been mainly the part of the duties of local government units, especially of gminas, which has to cope with other numerous statutory tasks, great interest in EU funds ï unfortunately not adequate to approved financial support, was observed during the implementation of pre-accession instruments in the years 2004-2006. The next 2007-2013 programming period, connected with the implementation of the National Cohesion Policy, has created new opportunities for the improvement of sport and recreation infrastructure in Poland, including the Kujawsko-Pomorskie voivodship, and has enabled to overcome the distance in the relation to Western European standards in this scope.

The greatest activity within the gain of the EU funds for the improvement of the accessibility and standard of sport and recreation infrastructure has been observed in local government units, mainly in gminas, which achieving financial support for this type of infrastructure have been tending to improve competitiveness, create recognizable image, but first of all improve their residentsôquality of life, both in objective and subjective dimensions, mainly in rural areas and little towns.

The development of sport as the important field of life having great social (e.g., for quality of life, the accessibility of infrastructure and services), economic (especially within the creation of new jobs, dynamic development of tourism) and branding (branding of cities, regions and countries) mainly depends on the accessibility and the high standard of sport and recreation infrastructure. The conducted research has shown that Poland as well as the Kujawsko-Pomorskie voivodship have been on the best track to achieve the best results in this field, while implementing the EU cohesion policy.

\section{References}

[1] BAőSKI, J., (2008). Wiejskie obszary sukcesu gospodarczego, Studia Obszarów Wiejskich, Wyd. Bernardinum, Warszawa, XIV. 
[2] BASIőSKA-ZYCH, A., LUBOWIECKI-VIKUK, A.P., (2010). Interwencjonizm samorzŃNlowy w obszarze turystyki i rekreacji w wybranych paজtwach Unii Europejskiej, Oeconomia, vol. 9, iss. 4, pp. 2537. ISSN 2353-4435.

[3] Biağ ksiňga na temat sportu., (2007). Available at: <http://eur-lex.europa.eu/legalcontent/PL/ALL/;jsessionid=HMLYT9SQ1vJpkz7d1dkPBTnX1G0WVnqwCQnLswnyTdlZYYVGlklc!2095688871?uri=CELEX:52007DC0391>

[4] BIEGAőSKA, J., (2013). Rural areas in Poland from a demographic perspective, Bulletin of Geography. Socio-economic Series, iss. 20, pp. 7ї 22. DOI 10.2478/bog-2013-0008.

[5] CAMPBELL, A., (1976). Subjective measures of well-being, American Psychologist, iss. 2.

[6] CAMPBELL, A., (1981). The sense of well-being in America: recent patterns and trends, McGraw-Hill, New York.

[7] CAMPBELl, A., CONVERSE, P., RODGERS, W., (1976). The quality of American life, Russel Sage Fundation, New York.

[8] DIENER, E., SUH, E., (1997). Measuring quality of life: economic, social, and subjective indicators, Social Indicators Research, 1997, vol. 40, iss. 1, pp. 189-216. ISSN 1573-0921. DOI 10.1023/A:1006859511756.

[9] FRENKEL, I., (1999). Infrastruktura wiejska w ukğhdach przestrzennych i jej wpğ nw na poziom Ũycia

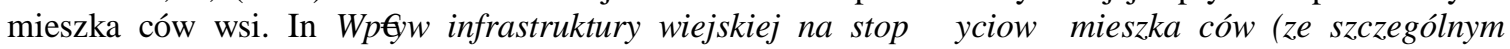
uwzglňdnieniem problemów biedniejszej czň́̂́si ludnoŜSi), Wyd. IRWiR PAN, Warszawa, pp. 13-32.

[10] GRZELAK-KOSTULSKA, E., HOĞOWIECKA, B., (2009). Zmiany czasu trwania Ũycia w Polsce na tle Europy. In Przyszộs Ŝ́ demograficzna Polski. Acta Universitatis Lodziensis. Folia Oeconomica, Uniwersytet Ğódzki, ĞódF, iss. 231, pp. 491-512.

[11] GRZELAK-KOSTULSKA, E., HOGOWIECKA, B., (2010). Przestrzenne zró Ũhicowanie czasu trwania Ũcia. In Zmiany obszarów miejskich $i$ wiejskich $w$ Ŝietle wybranych analiz demograficznych $i$ funkcjonalno-przestrzennych, Wydawnictwo Naukowe Uniwersytetu Mikoğıja Kopernika, ToruFFp. 3550.

[12] GRZELAK-KOSTULSKA, E., HOĞOWIECKA, B., (2013). Fundusze strukturalne jako czynnik stymulujన́ky rozwój sektora turystycznego w regionie kujawsko-pomorskim. In Środki unijne w gospodarce turystycznej, Uniwersytet Szczeciळki, Szczecin, II, pp. 73-90.

[13] GODLEWSKI, P., (2004). PodmiotowoŜ́ sportu a procesy globalizacyjne. In Podmiotowoŝ́ w edukacji

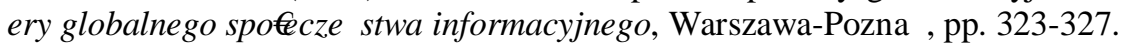

[14] GODLEWSKI, P., (2011). Globalny i lokalny wymiar wspóğzesnego sportu, Zeszyty Naukowe

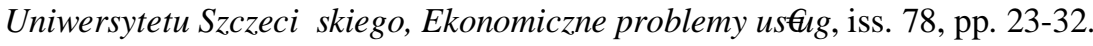

[15] GUS., (2013). JakoŜ Ũycia, kapitağspoğczny, ubóstwo i wykluczenie spoğczne w Polsce, Warszawa.

[16] HEFFNER, K., (2001). Transformacja ukğłdów osadniczych wsi a wielofunkcyjny rozwój obszarów wiejskich. In WieŜ i rolnictwo na przeğgmie wieków, Wyd. IRWiR PAN, Warszawa, pp.109-132.

[17] LIJEWSKI, T., (2004). Infrastruktura. In Fierla, I. (ed.), Geografia gospodarcza Polski, PWE, Warszawa, pp. 246-284.

[18] Gł CZAK, A., (2010). Wsparcie budowy i modernizacji obiektów rekreacyjno-sportowych z funduszy europejskich. In Studia Lubuskie, Tom VI, pp. 313-329.

[19] Ministerstwo Rolnictwa i Rozwoju Wsi. [online]. Available at: <http://www.minrol.gov.pl/pol/Wsparcierolnictwa-i-rybolowstwa/PROW-2007-2013/Dzialania-PROW-2007-2013>

[20] Ministerstwo Rozwoju Regionalnego. [online]. Available at:

<https://www.mrr.gov.pl/aktualnosci/fundusze_europejskie_2007_2013/Strony/finansowanie_sportu_z_unijnyc h_funduszy.aspx?N=T>

[21] Ministerstwo Sportu., (2007). Strategia Rozwoju Sportu w Polsce do Roku 2015, Warszawa.

[22] MOTEK, P., BOGACKA, E., (2012). Pozycja konkurencyjna Poznania w sporcie. In Pozycja konkurencyjna Poznania wŜ́ód metropolii krajowych $i$ miňdzynarodowych, Biblioteka Aglomeracji PoznaGkiej, PoznaFiss. 22, pp. 145-162.

[23] Narodowa Strategia SpójnoŜci. [online]. Available at:

<http://www.funduszeeuropejskie.gov.pl/wstepdofunduszyeuropejskich/strony/nss.aspx, DoA: 21 March 2014>

[24] Regionalny Program Operacyjny Województwa Kujawsko-Pomorskiego. [online]. Available at: <http://www.mojregion.eu/regionalny-program-operacyjny-wojewodztwa-kujawsko-pomorskiego/oprogramie.html, DoA: 21 March 2014>

[25] Regionalny Program Operacyjny Województwa Kujawsko-Pomorskiego na lata 2007-2013. [online]. Available at: <http://www.mojregion.eu/tl_files/mojregion/dokumentyrpo/Wazne\%20dokumenty/Dokumenty\%20programowe/Zal\%20do\%20uchwaly\%2070-151911\%20z\%20dn.\%2014.12.2011\%20_zm\%20RPO\%20WK-P\%202011.pdf, DoA: 1 April 2014> 
[26] SUSIENE, D., JURKAUSKAS, A., (1999). The Concepts of Quality of Life and Happiness ï Correlation and Differences. In Inzinerine Ekonomika-Engineering Economics(3), Work Humanism, pp 58-66. ISSN 1392-2785

[27] SZYMAöSKA, D., (2004). Changes in the Employment structure and the functions of Polish towns in the years 1984-2000. Current Politics and Economics of Russia, Eastern and Central Europe, vol. 19, iss. 4, pp. 7-27.

[28] SZYMAőSKA, D., BIEGAőSKA, J., (2011). Obszary wiejskie w Polsce w Ŝvietle analizy wybranych elementów infrastruktury i mieszkalnictwa. In Regionalne zró Ũ hicowanie rozwoju spoğcznogospodarczego na obszarach wiejskich, Bogucki Wydawnictwo Naukowe, PoznaFiss. 14, pp. 57-74.

[29] SZYMA̋̋ SKA, D., BIEGAőSKA, J., (2012). Infrastructure's and housing's development in the rural areas in Poland - some problems. Journal of Infrastructure Development, vol. 4, iss. 1, pp. 1-17. DOI 10.1177/0974930612449533.

[30] ŚRODA-MURAWSKA, S., (2013). Przestrzenne zróŬhicowanie poziomu rozwoju spoğcznogospodarczego Niemiec, NierównoŜ́i spoğczne a wzrost gospodarczy, Uniwersytet Rzeszowski, Rzeszów, iss. 31 , pp. 308-317.

[31] TRZEBIATOWSKI, J., (2011). JakoŜ́ Ũycia w perspektywie nauk spoğcznych i medycznych ï systematyzacja ujň definicyjnych, Hygeia Public Health, vol. 46, iss.1, pp. 25-31.

[32] Ustawa o samorzŃkzie terytorialnym $\mathrm{z}$ dnia 8 marca $1990 \mathrm{r}$. [online]. Available at: <http://isap.sejm.gov.pl/Download;jsessionid=E7961239290E8F4FFBC0ADD1964BA777?id=WDU1990 0160095\&type=2>

[33] WALCZAK, M., TOMCZAK, M., (2011). Poczucie jakoŜsi Ũycia jako efekt zaspokojenia potrzeb psychologicznych i zró Ũhicowania motywacji do aktywnoŜsi fizycznej, Zeszyty Naukowe Uniwersytetu SzczeciCkkiego, Ekonomiczne problemy usğıg, iss. 78, pp. 219-240.

[34] WHO., (2002). The world health report 2002 - Reducing Risks, Promoting Healthy Life, Geneva.

[35] WHOQOL., (1997). Measuring Quality of Life. [online]. Available at: <http://www.who.int/mental_health/media/68.pdf>

[36] WNUK, M., MARCINKOWSKI, J.T., (2012). JakoŜ́ Ũycia jako pojňcie pluralistyczne o charakterze interdyscyplinarnym, Problemy Higieny i Epidemiologii, vol. 93, iss. 1, pp. 21-26. 